\title{
1 Thessalonians 4.13-18 in Rabbinic Perspective
}

\author{
CANDIDA R. MOSS \\ Department of Theology, 130 Malloy Hall, University of Notre Dame, Notre Dame, \\ IN 46556, USA. \\ email: candida.moss@nd.edu
}

JOEL S. BADEN

Yale Divinity School, 409 Prospect St., New Haven, CT 06511, USA.

email: joel.baden@yale.edu

\begin{abstract}
1 Thessalonians 4.16-17 has occasioned much scholarly speculation regarding Paul's conception of the resurrected body, the character of those caught up in Christ, the ultimate fate of those who are caught up in the air, and Pauline eschatology in general. The interpretation of the passage may be illuminated by comparison with rabbinic traditions in which the righteous escape judgment and destruction in Sheol by flying and being borne aloft by clouds, traditions that, given Paul's Jewish heritage, could well stand in the background of 1 Thess 4.16-17.
\end{abstract}

Keywords: 1 Thessalonians, Paul, rabbinics, midrash, eschatology, rapture

\section{Introduction}

To say that the pericope on the eschatological hopes of 'those who have fallen asleep' in 1 Thess 4.16-17 has something of a storied interpretative history would be a gross understatement. The passage has attracted the attention of those interested in the timing of the eschaton, the history of the concept of the resurrection, the consolatory function of the letter, and the authorship and consistency of the Thessalonian correspondence. This is to say nothing of the vibrant interpretation of eschatological events depicted in this passage by modern Christians as evidence for 'the rapture'.

Despite the many critical approaches to the account and the rich discussions they have produced, the cultural and intellectual context of being 'caught up in the clouds together with [the raised dead and] the Lord in the air' has remained obscure. Among the Pauline epistles, the image is unique to 1 Thessalonians and appears-to many interpreters-to stand in stark contrast to other Pauline 
depictions of the eschaton. While the careful work of Helmut Koester has connected the image to Hellenistic military imagery and practice, and a number of scholars have discussed a rather amorphous midrashic quality to the account, the conceptual background for this verse is unclear and the mechanics of being caught up in the clouds are at best nebulous. ${ }^{1}$

The purpose of this paper is to reconsider the gathering of people to Christ in the clouds in the context of rabbinic eschatological traditions. It will show that even as 1 Thess 4.16-17 serves the larger consolatory agenda of the letter, and irrespective of the consistency of Paul's eschatological timetable, the notion of flying with Christ can be understood as part of an ancient Jewish reading tradition that dealt with the mechanics of the eschaton. Paul's description of the resurrection of the dead and eschatological flying may be considered part of a larger midrashic exegetical trend that describes the resurrection as suspension or flying in the air. Reading Paul in this context will illuminate other critical issues in treatments of 1 Thess 4.16-17, namely, Paul's conception of the resurrected body, the character of those caught up in Christ, the ultimate fate of those who are caught up in the air, and Pauline eschatology in general. Before turning to these rabbinic traditions, however, we will first review the dominant scholarly interpretations of the passage.

\section{Critical Approaches to 1 Thessalonians 4.13-18}

Traditional scholarship on 1 Thess 4.16-17 has focused on one of several issues: the situation at Thessaloniki that necessitated this statement, the relationship of this passage to Pauline thought about the resurrection in general, and the intellectual context of the passage. ${ }^{2}$ As with all of Paul's epistles, the situation at Thessaloniki and the occasion for the writing of the letter are frequently treated as the hermeneutical keys for its understanding. The precise dating of the letter is debated, but the occasion of the letter is just as opaque. ${ }^{3}$ Assuming the integrity of the letter, a number of scholars have argued that chs. 4-5, the parenetic section of

1 H. Koester, Paul and his World: Interpreting the New Testament in its Context (Minneapolis: Fortress, 2007) 59-60.

2 The scholarship on this question is very extensive and it is impossible to attempt even a summary here. For general bibliography on 1 Thess $4.13-18$ see J. A. D. Weima and S. E. Porter, An Annotated Bibliography of 1 and 2 Thessalonians (Leiden: Brill, 1998) 196-221. For an overview of the scholarship on this pericope, including an excursus on the monographs and articles on this subject in table form, see D. Luckensmeyer, The Eschatology of First Thessalonians (NTOA/STUNT 71; Göttingen: Vandenhoeck \& Ruprecht, 2009) 192-211. Luckensmeyer is correct when he remarks that 'attempts at expressing Paul's thought in these verses are crippled by the sizeable task of engaging the, often not mutually exclusive, theses of different authors' (192).

3 The calculation of Malherbe that the letter was written some four months after Paul's departure from Thessaloniki c. $50 \mathrm{CE}$ seems reasonable; see A. Malherbe, The Letters to the Thessalonians (AB 32B; New York: Doubleday, 2000) 72. 
the letter, contain Paul's message. Among the concerns that plagued the young Thessalonian community, the issue of the fate of 'those who have fallen asleep' (4.13-18) is one of preeminent importance. Members of the community have died and those who are left are thrown into crisis. The motivation in writing this section of the letter is to correct and to console the Thessalonians in their grief. ${ }^{4}$

For those interested in Pauline theology, 4.13-18 has raised questions about the development of Paul's thinking on the afterlife. 1 Thessalonians 4 can be read as conceptually discordant with the image of bodily transformation articulated in 1 Corinthians $15 .{ }^{5}$ Whereas in 1 Thessalonians 4 the dead are raised and the living gathered together in the clouds, in 1 Corinthians 15 Paul is clear that the dead will be transformed 'in the twinkling of an eye' (1 Cor 15.52). ${ }^{6}$ 1 Thessalonians 4 and 1 Corinthians 15 are not outright contradictory, but they presuppose very different interests and expectations. One way to reconcile the differences between these texts is to posit stages in the development of Paul's thought about the eschaton. Lüdemann, for instance, outlines three stages in Paul's thinking related to the delay of the parousia. ${ }^{7}$ This perspective on Pauline

4 That Paul is introducing the Thessalonians to this material for the first time can be inferred from the fact that he does not use the reminding language characteristic of the work. So G. D. Fee, The First and Second Letters to the Thessalonians (NICNT; Grand Rapids: Eerdmans, 2009) 164-5. It may even be the case that the Thessalonians themselves had raised the issue to Paul through Timothy, although Paul himself makes no mention of this. So E. Best, A Commentary on the First and Second Epistles to the Thessalonians (New York: Harper \& Row, 1982) 180.

5 The relationship between the raising of the dead in 1 Thess 4.17 and the transformation of the living and the dead in 1 Cor 15.51-52 has been the subject of heated debate. Some argue that 1 Thess 4.17 neither includes nor excludes transformation. See, for example, W. Radl, Ankunft des Herrn. Zur Dedeutung und Funktion der Parusieaussagen bei Paulus (BBET 15; Frankfurt: Lang, 1981) 151. Although his argument has not been especially persuasive and he does not consider non-Pauline literature at any length, Gillman argues that transformation is implicit in 1 Thessalonians. See J. Gillman, 'Signals of Transformation in 1 Thessalonians 4:13-18', CBQ 47 (1985) 263-81. So also R. A. Ward, Commentary on 1 \& 2 Thessalonians (Waco: Word, 1973) 106-7.

6 Mearns sums up the contrast, saying that Paul underwent a 'very marked and significant change in his eschatology'. C. L. Mearns, 'Early Eschatological Development in Paul: The Evidence of I and II Thessalonians', NTS 27 (1980-81) 137-57.

7 G. Lüdemann, 'The Hope of the Early Paul: From the Foundation-preaching at Thessalonika to 1 Cor. 15:51-57', PRSt 7 (1980) 195-201. In the first stage, during his visit to Thessaloniki, Paul had stated that practically all Christians would live to see the return of Jesus from heaven (1 Thess 1.10). The deaths of some Christians in Thessaloniki prompted Paul to modify his position and argue that Christians would all be translated together, the dead being revivified after death (1 Thess 4 ). The third stage envisions the parousia as a future event in which translation is replaced by resurrection (1 Cor 15). Lüdemann's theory recalls the classical developmental theories of E. Teichmann, Die paulinischen Vorstellungen von Auferstehung und Gericht und ihre Beziehung zur jüdischen Apokalyptik (Freiburg and Leipzig: Teubner, 1896) and R. H. Charles, Eschatology: The Doctrine of a Future Life in

\section{CAMBRIDGE JDURNALS}


eschatology has led to the characterization of $4.16-17$ as an interim solution. An undeveloped teaching about the resurrection is employed here, it is argued, as part of an effort to console a distraught fledgling community. Yet, although Paul's letters are always purposeful (even if they are not always occasional), this does not render his theology ad hoc. The notion of the Day of the Lord employed in 1 Thess 4.16-17, even if it does not represent Paul's final statement on the matter, may yet articulate a sophisticated theory of eschatological deliverance.

\section{The Cultural and Intellectual Background of 1 Thessalonians 4.16-17}

In 4.17 Paul states that 'Then we who are alive, who are left, will be caught up in the clouds together with them to meet the Lord in the air; and so we will be

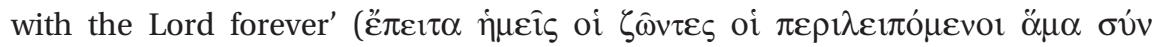

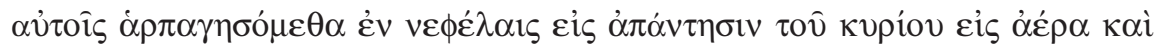

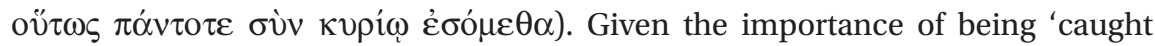
up in the clouds' for the development of ideas about the Day of the Lord among members of the Jesus movement, a great deal of attention has been paid to the religious and cultural background to the image.

The eschatological and heavenly focus of the passage has led many to examine scriptural portraits and contemporary eschatological expectations about the endtimes. The description of the Son of Man in Daniel 7 has featured prominently in discussions of 1 Thessalonians $4 .^{8}$ The references to the descent of the Lord, the cry of command, the trumpet sound, and the archangel's call resonate with descriptions of the Son of Man's descent to earth on clouds at the end of the age (Dan 7.13). The use of a similar notion in Mark 13.26 and 14.62 has led some to conclude that Paul was drawing upon a traditional saying about the eschaton that may have been derived from Jesus himself. ${ }^{9}$

Israel, Judaism, and Christianity (London: Black, 1899). The development of Paul's thinking about the resurrected body is also a feature in J. Becker, Auferstehung der Toten im Urchristentum (SBS 82; Stuttgart: Katholisches Bibelwerk, 1976) 46-54; Becker, 'Die Frage nach den entschlafenen Christen in 1 Thess 4,13-18', Jahrbuch des evangelischen Bundes 23 (1980) 45-60; and W. Wiefel, 'Die Hauptrichtung des Wandels im eschatologischen Denken des Paulus', $T Z 30$ (1974) 65-81. One criticism of these developmental models has been the underlying model of change and development that they employ. See G. Bornkamm, Paul (London: Hodder \& Stoughton, 1971) 222; F. Guntermann, Die Eschatologie des hl Paulus (NAbh 13/4-5; Münster: Aschendorff, 1932) 38-51.

8 Fee, Thessalonians, 180.

9 So C. A. Wannamaker, The Epistles to the Thessalonians: A Commentary on the Greek Text (NIGTC; Grand Rapids: Eerdmans, 1990) 175; Leon Morris, 1 and 2 Thessalonians (TNTC 13; Grand Rapids: Eerdmans, rev. ed. 1984) 94. 
In both Dan 7.13 and Mark 13.26, the clouds serve as a mode of transport rather than a final destination for the resurrected. Slavonic Enoch uses similar mechanics for the heavenly ascent of Enoch. ${ }^{10}$ That clouds could serve as a mode of transportation for individuals is clear. Whether or not this is the case for 1 Thessalonians, however, is ambiguous. Paul merely states that they will be together with Christ forever. There has been considerable scholarly resistance to the idea that the clouds are the destination of the risen. Marshall, for example, states, 'it is improbable that this permanent union takes place in the air or in heaven'. ${ }^{11}$ Gordon Fee aptly remarks, 'Christians tend not to be satisfied with leaving them "in the air", as it were'. ${ }^{12}$ Yet, as Fee goes on to note, Paul only twice identifies the final location of believers as being heaven (2 Cor 5.1 and perhaps Col 1.5). Paul is not interested, Fee says, in eschatological geography. Fee may be correct, but-in the meantimethe situation in 1 Thessalonians remains ambiguous.

Given the taut literary connection that reliance upon dominical sayings and Dan 7.13 demands, some have elected for a more general apocalyptic background for 1 Thess 4.16-17. ${ }^{13}$ If Paul does here adapt apocalyptic Jewish perspectives on the end of days, he would seem to be reversing the traditional view of those left alive at the eschaton. ${ }^{14}$ Whereas a number of apocalyptic texts stress the privileged status of the final generation, Paul is clear to emphasize that there is no advantage for those who survive to the end. ${ }^{15}$

The significance of meeting 'in the air' has likewise drawn a great deal of attention. Some have argued that first-century Judaism viewed the air as the dwelling place of demons. ${ }^{16}$ Ephesians 2.2 describes Satan as the 'ruler of the kingdom in the air'. In this instance the reunion 'in the air' would serve to designate Christ as

10 Slavonic 2 En. 3.1-3; trans. F. I. Anderson, in The Old Testament Pseudepigrapha, vol. 1 (ed. J. H. Charlesworth; ABRL; New York: Doubleday, 1983) 110. This parallel is noted by J. E. Frame, A Critical and Exegetical Commentary on the Epistles of St. Paul to the Thessalonians (ICC; New York: Scribner's, 1912) 175-6.

11 I. H. Marshall, 1 and 2 Thessalonians (NCB; Grand Rapids: Eerdmans, 1983) 131.

12 Fee, Thesssalonians, 181.

13 See V. P. Furnish, 1 Thessalonians, 2 Thessalonians (ANTC; Nashville: Abingdon 2007) 102-3, who envisages 'partial parallels' between Paul and Jewish apocalyptic traditions (102). Other posited parallels include LXX Exod 19.16-18, in which clouds, meeting, descent, and trumpets appear. So Ward, 1 \& 2 Thessalonians, 108.

14 D. E. H. Whiteley, Thessalonians (New Clarendon Bible; Oxford: Oxford University, 1969) 67, proposes that a misunderstanding over the relative rewards of the deceased versus the living is in view here.

15 Cf. Dan 12.12-13; 4 Ezra 6.18-28; 7.27-28; 13.24; Pss. Sol. 17.44; Sib. Or. 3.367-80. D. J. Harrington, First and Second Thessalonians (SP 11; Collegeville: Liturgical, 1995) 242. An alternative reading of this passage would stress that all meet their fate together. This would rest on the notion that everyone is lifted up in the air. Cf. Epistle of Barnabas 20.2; 51.13; Pseudo-Philo Biblical Antiquities, 19.20.

16 L. Morris, The First and Second Epistles to the Thessalonians (NICNT; Grand Rapids: Eerdmans, 1991) 146; Fee, Thesssalonians, 180.

\section{CAMBRIDGE JDURNALS}


regnant over evil forces. Certainly this reading has some merit to it, but the spatial contrast in 1 Thess $4.16-17$ is between the earth and the air. The opening of the earth and releasing of the dead from Sheol has rendered the ground treacherous. The air is, by comparison, a place of safety. If there is an echo of the traditional evil forces that occupy the air then it is ironic that in the eschatological reversal their dwelling has become the place of safety.

In Paul and his World, Helmut Koester has observed that $\pi \alpha \rho \circ v \sigma i \alpha$, the technical terminology used to describe the eschatological coming of Jesus in 1 Thess $2.19 ; 3.13 ; 4.15$, and 5.23 , is not used in pre-Christian apocalyptic literature. ${ }^{17}$ Building on the work of Petersen, Koester notes that if there is a technical antecedent for the use of this term in 1 Thessalonians it is in the description of the arrival of a king or emperor. ${ }^{18}$ From this Koester argues that Paul describes the coming of the Lord like a king or Caesar in order to stress the need for community preparedness. ${ }^{19}$ The scene of reunion with Christ is also painted with imperial strokes. Paul uses $\alpha \pi \alpha ́ v \tau \eta \sigma ı \varsigma$, a technical term for the act of going out to meet a dignitary or monarch from another city, to describe meeting the Lord in the clouds in v. $17 .^{20}$ In Koester's reading, therefore, the parousia casts the Thessalonian community as a united delegation from a city that goes out to greet the visiting emperor. In short, 'it is not possible to understand this passage as a statement about the 'rapture' of the believers into heaven'. ${ }^{21}$ This is good military etiquette.

The connection between imperial language and imagery and 4.13-18 is certainly illuminating, but perhaps we have been too quick to dismiss apocalyptic and eschatological analogues for the scene. ${ }^{22}$ Readers of 1 Thessalonians have often remarked upon the somewhat midrashic quality of the text. ${ }^{23}$ A closer

17 Koester, Paul and his World, 59-6o. Koester cites the work of A. Oepke, “ $\pi \alpha \rho o v \sigma i ́ \alpha ”, ~ T D N T 5$ (1967) 859-71 and T. Holtz, Der erste Brief an die Thessalonicher (EKKNT 13; NeukirchenVluyn: Neukirchener, 1986) 119 as evidence for the linguistic background. The origins of this idea are found in E. Peterson, 'Die Einholung des Kyrios', ZSth 7 (1929/30) 682-702. Criticisms of Petersen's argument have been offered by J. Dupont, ' “Avec le Seigneur” a la Parousie', $\Sigma Y N$ XPI $\Sigma T \Omega I$ : L'union avec le Christ suivant Saint Paul (ed. Jacques Dupont; Paris: Desclée de Brouwer, 1952) 39-79 and M. Cosby, 'Hellenistic Formal Receptions', BBR 4 (1994) 15-34. Despite these criticisms, Petersen has been followed by R. H. Gundry, 'A Brief Note on "Hellenistic Formal Receptions and Paul's Use of $\mathrm{A \Pi ANTH} \Sigma \mathrm{I} \Sigma$ in 1 Thessalonians 4:17",' BBR 6 (1996) 39-41; Marshall, 1 and 2 Thessalonians, 131; Morris, The First and Second Epistles, 146.

18 For the use of the term in imperial contexts see B. Rigaux, Saint Paul Les épitres aux Thessaloniciens (Paris: Gembloux Duculot, 1956) 198.

19 An interest in community is also advocated by R. S. Ascough, 'A Question of Death: Paul's Community-Building Language in 1 Thessalonians 4:13-18', JBL 123 (2004) 509-30.

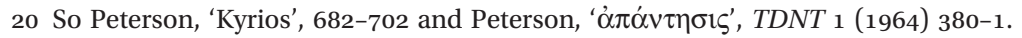

21 Koester, Paul and his World, 60 n. 37.

22 C. S. Keener, The Historical Jesus of the Gospels (Grand Rapids: Eerdmans, 2009) 534 n. 209.

23 Lars Hartman, for instance, argued that Paul based 1 Thess 4.13-18 on an early midrash on Dan 7 that stemmed from Jesus himself. Hartmann's theory can account for the trumpet 
examination of rabbinic texts pertaining to the Day of the Lord will reveal that there were traditions in which the righteous escaped judgment and destruction in Sheol by flying and being borne aloft by clouds.

\section{Rabbinic Texts about Flying and the Day of the Lord}

It should be noted at the outset that dating rabbinic traditions is notoriously difficult. Although we may be able to date the texts in which invididual interpretations are found, these texts are anthologies, thematically organized collections of originally independent, earlier (sometimes considerably earlier) midrashim. ${ }^{24}$ To say that Midrash Tehillim (to take an example from the discussion below) dates to the ninth century $\mathrm{CE}$, then, is not to say that the material contained therein is of equally late date; the bulk of the individual midrashim are from much earlier. ${ }^{25}$ Moreover, even the original form of an individual midrash cannot provide a precise date for the concepts exploited; it is safe to say that the fixing of a concept in a midrashic form represents the end of a lengthy process of oral development. Thus when we draw parallels between Paul and various midrashim, what we are talking about is the plausibility of Paul's familiarity with the concepts-not the texts themselves-inherent in the rabbinic interpretation.

These parallels occur in two major strands. The first is connected with Isa 60.8: 'Who are these who fly like a cloud, like doves to their cotes?' According to the usual scholarly understanding of this verse, the white clouds and doves are likened to the white sails of the ships bringing the far-flung Israelites back from the diaspora (Isa 60.9). ${ }^{26}$ Although part of a larger prophetic unit that is clearly

call but hardly explains the unusual mechanics of the heavenly ascent. L. Hartman, 'The Eschatological Discourse and the Letters to the Thessalonians', Prophecy Interpreted: The Formation of Some Jewish Apocalyptic Texts and of the Eschatological Discourse, Mark 13 Par (ConBNT 1; Lund: Gleerup, 1966) 178-205.

24 On dating rabbinic traditions, see B. J. Bamberger, 'The Dating of Aggadic Materials', JBL 68 (1949) 115-23.

25 Cf. W. G. Braude, The Midrash on Psalms, vol. 1 (Yale Judaica Series 13; New Haven: Yale University, 1959) xi; J. L. Kugel, Traditions of the Bible: A Guide to the Bible as it Was at the Start of the Common Era (Cambridge, MA: Harvard University, 1998) 927.

26 Cf., e.g., G. von Rad, Old Testament Theology, vol. 2 (OTL; Louisville: Westminster John Knox, 2001) 295; B. S. Childs, Isaiah (OTL; Louisville: Westminster John Knox, 2001) 497. A different approach is taken by W. C. Bouzard Jr, 'Doves in the Windows: Isaiah 60:8 in Light of Ancient Mesopotamian Lament Traditions', David and Zion (ed. B. F. Batto and K. L. Roberts; Winona Lake: Eisenbrauns, 2004) 307-17, who argues that the doves are unrelated to the ships of Tarshish in the subsequent verse but instead describe the return of God's presence to the restored Temple. His argument regarding the doves, though intriguing, does not account for the first half of Isa 6o.8; his attempt to reinterpret the word commonly taken as 'cloud' as an architectural feature of the Temple, perhaps 'canopy', is unconvincing. There is no

\section{CAMBRIDGE JDURNALS}


eschatological, this verse in its original context is no more than metaphor and a simile, with little import: no one was actually imagined to be flying. ${ }^{27}$ In rabbinic treatments, however, the meaning of this verse is dramatically expanded. In accord with the standard midrashic hermeneutic, Isa 60.8 was read not as the first part of a comparison with the sails of ships, but rather as a meaningful independent unit. ${ }^{28}$ What the rabbis retained from the biblical context was the connection between 'flying as a cloud' and the eschaton; the novelty of the midrashic treatment is the literality with which this prophetic statement was now understood. The words 'who are these that fly like a cloud?' are taken to mean precisely what they say: there were those-to be defined by the interpreter-who actually flew, or will actually fly, like a cloud. In addition, in the rabbinic period we find a much more developed eschatology, one that had been influenced both by the restoration eschatology typical of Isaiah 60, for instance, and also by the apocalyptic tendencies of later biblical and post-biblical writings. ${ }^{29}$ Thus for the rabbis 'flying as a cloud' from Isa 60.8 was connected not just with the restoration of the Temple, but with the entire concept of the world to come, the eschatological era that will follow the Day of Yahweh.

These two new features-the developed eschatology and the literal reading of the verse-are present to a greater or lesser degree in a range of midrashic discourses on Isa 60.8. In the Mekhilta, in a list of ways in which God's means of 'smiting' (punishment) are the same as his means of 'healing', we read: 'When he exiled Israel, he did not exile them except by means of clouds, as it is said: "Alas! Yahweh in his anger has beclouded [fair Zion]" (Lam 2.1); and when he assembles them, he will not assemble them except by means of clouds, as it is said: "Who are these who fly like a cloud?" (Isa 60.8)' (Mekhilta Beshallah 6). ${ }^{30}$

reason, in fact, that both the comparison with the sails of the ships and the notion of the return of the deity's presence could not be part of the prophet's intended meaning here.

27 It is perhaps for this reason that when scholars have tried to find verses in the Hebrew Bible that mention 'clouds' as possible parallels with 1 Thess 4.17 they have uniformly ignored Isa 60.8 .

28 On the individual verse as the significant interpretive unit in midrash, see J. L. Kugel, 'Two Introductions to Midrash', Midrash and Literature (ed. G. H. Hartman and S. Budick; New Haven: Yale University, 1986) 77-103 (esp. 93-103).

29 On the disparate influences on and diverse forms of rabbinic eschatology, see E. E. Urbach, The Sages: Their Concepts and Beliefs, vol. 1 (2d ed.; Jerusalem: Magnes, 1987) 649-92 (esp. 649-52).

30 Following the critical text of J. Z. Lauterbach, Mekhilta de-Rabbi Ishmael, vol. 1 (Philadelphia: Jewish Publication Society, 2nd ed. 2004) 159; all translations of rabbinic material are mine [JSB]. As the next entry in this list the second half of Isa 60.8 is adduced: 'When he scattered them, he did not scatter them except like doves, as it is said: "If any survivors survive, they shall go to the mountains, like doves of the valleys, all of them moaning, each for his iniquity" (Ezek 
Although both the eschatological and the literal features of the interpretation are somewhat muted here, they may be understood by analogy with a similar midrash in which these features are more clearly present. In Midrash Tehillim, we find commentary on a verse from Qohelet: " "What has been is what will be" (Qoh 1.9). This verse is explicated: "Just as the Holy One, blessed be he, lifted Israel in clouds of glory and surrounded them and bore them, as it is said, 'I lifted you on eagles' wings" (Exod 19.4), thus he will do to them in the future, as it is said, "Who are these who fly like a cloud?"' (Midrash Tehillim 48.4). ${ }^{31}$ In both midrashim an analogy is drawn between an act of God in the past involving clouds and the restoration of Israel in the eschatological era. No longer are we dealing with ships, but rather with the Jewish people themselves: it is the people who are likened to the clouds-crucially, not in their appearance, but in their movement.

An even clearer connection between Isa 60.8 and the messianic age is made in Shemot Rabbah 51.8, in the context of the analysis of Exod 38.21, 'These [אלה] are the records of the Tabernacle'. The midrash explains that the building of the Tabernacle atoned for the Israelites' sin with the golden calf, as is proved by the use of the word אלה, 'these', in both Exod 38.21 and 32.4: 'This [אלה] is your god, O Israel'. It continues: 'The Holy One, blessed be he, said to Israel, "In this world I have been reconciled to you by means of 'these' [אלה]; so too in the world to come, as it is said... 'Who are these [אלה] who fly like a cloud, like doves to their cotes?'”'

Both the eschatological and literal features reach a head in yet another midrash. According to Tanhuma Tzav 12, at the eschaton Jerusalem will be lifted by clouds through the seven heavens until it reaches the throne of glory. The transformation of Jerusalem is not simply in its vertical location, however: the Jerusalem of the world to come will be the physical location for the eschatological age, according to this rabbinic discussion; it will be a vastly expanded place. Like Jerusalem itself, those people who are taken up to the heavenly city will similarly be lifted by clouds: '[God] will send clouds and they will fly, as it is said, "Who are these who fly like a cloud?"'32 If this tradition

7.16); and when he brings them back, he will not bring them back except like doves, as it is said: "And like doves to their cotes" (Isa 60.8)'.

31 This and other citations of Midrash Tehillim are taken from the edition of Buber (Jerusalem: Wagschal, 1965-66). That 'in the future' refers to the world to come is clear from the second explication of Qoh 1.9 immediately following the one quoted above: 'Just as the Israelites sang a song in the wilderness and the well sprang up for them [Num 21.17], so in the world to come they will sing a song and the waters will spring up for them [Ps 87.7]'.

32 This midrashic text was already adduced in connection with 1 Thess $4.16-17$ by Paul Billerbeck, Kommentar zum Neuen Testament aus Talmud und Midrasch (6 vols.; Munich: Beck, 1922-56) 3.635-6 (who took it from Tanhuma [Buber edition] Tzav 16). 
is connected with 1 Thess 4.16-17, then those who are taken up may be viewed as traveling via cloud to reach the eschatological Jerusalem in the seventh heaven.

There is a different tradition regarding the location of the eschatological Jerusalem, however, which comes from the Talmud: 'Rabbah said in the name of R. Yohanan: In the future the Holy One, blessed be he, will lift Jerusalem three parasangs high, as it is said, "She [Jerusalem] shall rise and stay in her place" (Zech 14.10)...and lest you should think it is painful to go up [to it], Scripture teaches: "Who are these who fly like a cloud, like doves to their cotes?"' (b. Bab. Bat. 75b). According to this midrash, like that just cited, the inauguration of the eschatological era will be marked by the expanding and lifting of Jerusalem high in the air; not to the seventh heaven, however, but merely as high as the clouds. ${ }^{33}$ The midrash thus positions the world to come as a physical space floating in the clouds; it then raises the question of how the righteous, once the eschatological Jerusalem has been raised, will get there. Since those who will participate in the world to come will have to travel up to the city, will the journey be painful? Not at all: they will fly like clouds, as Isa 60.8 says.

The relevance of the rabbinic interpretations of Isa 60.8, and particularly those of the last two passages quoted above, for the image employed by Paul in 1 Thess 4.17 should be evident. In the rabbinic traditions, at the advent of the eschaton the righteous will fly up to the new eschatological Jerusalem, either in the seventh heaven or floating in the clouds. One scholarly ambiguity raised by 1 Thess 4.17 has been the eventual fate of those gathered together in the clouds. Do they return to earth or ascend to heaven? The Hellenistic parallels amassed by Koester imply that the imperial Christ and the faithful delegation of Thessalonians will return to earth. Correspondences with Daniel 7 and other Jesus Movement traditions (e.g. Mark 13:24-27) about the eschaton suggest that Christ and the Jesus-followers will return to heaven, as does the tradition from Midrash Tanhuma. Yet the scene, as described by Paul, does not clearly point to either of these solutions; 1 Thess 4.17 merely states that they will meet the Lord in the air and 'so will be with the Lord forever'. The idea that those who have ascended into the clouds will simply remain in the clouds with the Lord has proven unsatisfying to NT scholars. The events seem to be left unresolved. The rabbinic idea preserved in the Talmud that Jerusalem also ascends to the clouds and that people will dwell there offers a modified version of the popular Second Temple idea of a 'heavenly Jerusalem' or 'heavenly Temple'. ${ }^{34}$ While it

33 See the continuation of the discussion: 'R. Papa said: We can derive from this that a cloud rises three parasangs'.

34 On the heavenly Jerusalem or Temple in Second Temple writings, see S. Safrai, 'The Heavenly Jerusalem', Ariel 23 (1969) 11-16; E. Urbach, 'Heavenly and Earthly Jerusalem', Jerusalem through the Ages: The Twenty-Fifth Archaeological Convention, October 1967 (ed. J. Aviram; Jerusalem: Israel Exploration Society, 1968) 156-71; D. Flusser, 'Jerusalem in Second 
would be an overstatement to say that the Thessalonians are promised continued existence with Christ in a nebulous Jerusalem, it is worth considering the possibility that, as some strains of ancient Jewish thought maintained that post-eschatological existence would be located in the clouds, Paul, given his Jewish heritage, may have been familiar with these ideas. The impulse to come down firmly either on terrestrial or celestial ground neglects all the space in between.

While the rabbinic treatment of Isa 60.8 provides interesting parallels and points of contact with 1 Thess 4.17 , another analogue is available. In Num 16.32-33, the rebellious Korah and his 250 followers are swallowed by the earth, which miraculously opens to consume them. In Num 26.11, however, we learn that the sons of Korah did not die along with their father, though no explanation is given for how this came to pass. The opportunity for midrash here is apparent, and the rabbis did not let it slip through the crack. A number of different solutions were offered. In one interpretive strain, exemplified by Pseudo-Philo, Korah's sons survived because they did not participate in the rebellion in the first place; they were, in fact, entirely opposed to their father's actions. ${ }^{35}$ More common is the notion that Korah's sons initially followed their father in rebellion, but at the moment that the earth began to open and swallow them they repented and were saved. Within this line of thought there is a variety of views as to precisely how the Korahites were saved from Sheol. According to Midrash Tehillim 1.15, Korah's sons were left standing on solid ground while the earth opened up around them. A more widespread view is that three pillars arose in Gehenna on which the three sons stood, suspended above the pit but still covered by the earth when it closed again. The Korahites are thus, according to this reading, in an intermediate state: not quite in Sheol, but not on earth either; not quite dead, but not quite living. It is from this subterranean vantage point that the sons of Korah are supposed to compose and recite the Psalms attributed to them (Pss 42-49; 84-85; 87-88). ${ }^{36}$ At the

Temple Literature', Judaism of the Second Temple Period, vol. 2 (Grand Rapids: Eerdmans, 2009) 44-75; J. Klawans, Purity, Sacrifice, and the Temple: Symbolism and Supersessionism in the Study of Ancient Judaism (Oxford: Oxford University, 2006) 128-42. The idea appears, of course, in Heb 12.22; for discussion see H. W. Attridge, The Epistle to the Hebrews (Hermeneia; Minneapolis: Fortress, 1989) 222-5. In Gal 4.26 Paul also has a notion of a Jerusalem above.

35 Pseudo-Philo Biblical Antiquities 16.4-6. Unique in this treatment is the notion that Korah had seven sons, rather than the usual three (those named in Exod 6.24).

36 For this view, see Bemidbar Rab. 18.20; b. Sanh. 110a-b; Tanhuma Korah 11; and Rashi on Num 26.11. The Korahite Psalms may in fact be the root of the entire tradition. It is almost universally recognized that Num 26.11 is part of a secondary insertion in the priestly census list of Num 26, the insertion comprising, according to most, 26.8-1 1; cf. A. Kuenen, An Historico-Critical Inquiry

\section{CAMBRIDGE JDURNALS}


time of the eschaton, God will remove the Korahites from their place in Gehenna. $^{37}$

It is the last midrashic explanation for the survival of the Korahites, however, that is most relevant to the discussion of 1 Thess 4.17. The explication of Ps 46.8 in Midrash Tehillim 46.3 begins as follows: " "Yahweh of hosts is with us" (Ps 46.8). The sons of Korah said to the righteous, "Do not fear; we have seen all the miracles which he did for us", as it is said, "The earth opened its mouth and swallowed them and their households" (Num 16.32). "And where were we at that time? In mid-air [באויר העולם]", as it is written, "The sons of Korah did not die" (Num 26.11)'. According to this midrash, when the earth opened to swallow the rebels, Korah's sons were saved not by being provided with solid ground to stand on, but by being taken up into the air. ${ }^{38}$ This miracle was not, however, a one-time occurrence, restricted to the past; it is, in fact, the model for the separation of the wicked from the righteous on the Day of Yahweh, as the midrash goes on to state: 'Thus the sons of Korah said, "Do not fear, O righteous, the terror of the day of judgment, for you will

into the Origin and Composition of the Hexateuch (London: MacMillan \& Co., 1886) 100; A. Dillmann, Die Bücher Numeri, Deuteronomium und Josua (Kurzgefasstes exegetisches Handbuch zum Alten Testament; Leipzig: Hirzel, 2nd ed. 1886) 173; H. Holzinger, Numeri (KHC 4; Tübingen: J. C. B. Mohr [Paul Siebeck], 1903) 132; B. Baentsch, Exodus-LeviticusNumeri übersetzt und erklärt (HKAT I/2; Göttingen: Vandenhoeck \& Ruprecht, 1903) 630; G.

B. Gray, A Critical and Exegetical Commentary on Numbers (ICC; Edinburgh: T. \& T. Clark, 1903) 389-90; M. Noth, Numbers (OTL; Philadelphia: Westminster, 1968) 205-6; E. Blum, Studien zur Komposition des Pentateuch (BZAW 189; Berlin: de Gruyter, 1990) 132-3 n. 128. This insertion is most likely to be attributed to a late, post-redactional hand, and was intended to address the question of how it is that Korah and his followers perished and yet his sons composed the Psalms attributed to them (cf., e.g., A. B. Ehrlich, Miqra ki-peshuto [3 vols.; New York: Ktav, 1969] 1.295; J. Scharbert, Numeri [NEchtB 27; Würzburg: Echter, 1992] 106-7). The conflict between the narrative of Num 16-in which the sons of Korah are not mentioned-and the existence of the Korahite Psalms (and perhaps, as some have suggested, the references to the Korahites as cultic servants in 1 Chr 9.19) drives not only the insertion of Num 26.11 but also the midrashic material that grew around it (as recognized by Kugel, Traditions, 791-2). Given the evident lateness of the secondary insertion in Num 26.11, it is tempting to speculate that the biblical passage represents an early stage of the same midrashic process that led to the stories of Midrash Tehillim, just as we find midrashic elements in some later biblical books (e. g., famously, the harmonistic treatment in $2 \mathrm{Chr} 35.12-13$ of the laws of the Passover sacrifice from Deut 16.7 and Exod 12.8-9).

37 Bem. Rab. 18.20.

38 This understanding is re-emphasized in the treatment of Ps 49.16 in the same midrashic collection: " "But God will ransom my life [נפשי] from the power of Sheol" (Ps 49.16), because we [i.e. the sons of Korah, the authors of this psalm] were not in his [Korah's] counsel. "He will take me. Selah" (Ps 49.16), which is as it is said, "They became a sign" (Num 26.10), proving that he [God] stationed them in mid-air' (Midrash Tehillim 49.3). 
not be seized along with the wicked, just as we were not seized", as it is said, "Therefore we will not fear when the earth is changed" (Ps 46.3)'.

The state of affairs envisioned here is that the Day of Judgment, the eschaton, will be essentially identical to the moment at which the earth opened and swallowed Korah and his followers. On the Day of Judgment, when the wicked are separated from the righteous, the wicked will fall into the gaping earth, down to Sheol, while the righteous will not fall, but will be lifted up into the air. The same picture of what will happen on the Day of Judgment can be found in the Talmud also, in part of the commentary on the classic passage from the Mishnah ( $m$. Sanh. 10.1-3) describing which groups of people will be denied access to the world to come: 'And should you ask of those years to come in which the Holy One, blessed be he, will renew his world, as it is said, "Yahweh alone will be exalted on that day" (Isa 2.11), what will the righteous do?, the Holy One, blessed be he, will make them wings like eagles and they will fly over the face of the waters, as it is said, "Therefore we will not fear when the earth is changed and the mountains melt into the heart of the sea" (Ps 46.3)' (b. Sanh. 92b). Although in the talmudic passage there is no direct mention of the sons of Korah, it is noteworthy that the prooftext for the notion that the righteous will float in the air at the Day of Judgment is the very same prooftext adduced in Midrash Tehillim 46.3 above-the Korahite Ps $46.3 .^{39}$

The midrashic traditions associated with the survival of the sons of Korah contain a number of features that are reminiscent of 1 Thess 4.17. There is obviously the eschatological frame; the notion that the righteous will fly in the air; and, interestingly, the consolatory pedagogical function of the description. Just as Paul addresses the fears of the Thessalonian community, so too the midrash about the sons of Korah constitutes a direct address to the righteous: 'Do not fear', for you will not share the fate of the wicked when the eschaton comes. Thus the midrash is similar to 1 Thess 4.17 not only in content, but also in function. Just as Paul consoles the Thessalonians about their eventual rescue from death so too the Korahite psalms serve as a means of reassurance and consolation. Both texts use the explicatory device of floating above the mouth of Sheol as a means of reassurance. They will, literally, be snatched from the jaws of death and borne away from danger. ${ }^{40}$

39 The one significant difference between the two versions is the length of time attributed to the 'Day of Yahweh': in Midrash Tehillim it appears to be a single moment on a single day, while the talmudic passage reflects the tradition that the world to come would be preceded by a lengthy period of desolation and destruction of the world as we know it. Thus the driving question for the Talmud is what the righteous will be doing during that long period; the answer, however, is the same as that given for the Korahites: they will float in mid-air.

40 It is worth noting that Paul is well aware of Korahite traditions and alludes to them in 1 Cor 10.10. See discussion in F. Watson, Paul and the Hermeneutics of Faith (London: T\&T Clark, 2004) 366-7. We are grateful to John Barclay for this reference.

\section{CAMBRIDGE JDURNALS}


These two strands of midrashic eschatological expectation can assist us in addressing yet another question: Who are the people that are caught up in the air? A specific point of debate in modern scholarship has been the identity of those gathered together by Christ. Grammatically the final clause of 4.16 (oi

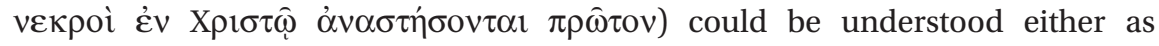
'those who are dead in Christ will rise' or 'the dead will rise in Christ'. ${ }^{41}$ Theologically the difference between these versions is of great importance. Does Paul envision that all will be resurrected for universal salvation, as Origen would have it, or that only Jesus-followers will be resurrected? Paul is somewhat ambiguous on this point and both situations are attested in other extant early Christian literature. The model present in rabbinic texts offers a third possibility: only Christ followers-both alive and dead-are raised up in the clouds and the living wicked join the non-Christian dead in Sheol.

\section{Conclusion}

Reading Paul in light of rabbinic notions of the Day of the Lord reconfigures our understanding of the import and substance of 1 Thess 4.17. Even if there is a shift in Paul's thinking about the resurrected body from Paul's original teaching on the eschaton to 1 Thess 4.17, and then again to 1 Cor 15.51-52, and even if Paul is addressing a specific situation in Thessaloniki, this does not reduce the image of the resurrection in 1 Thessalonians to a mere conceptual patch. The idea that people will be saved from Sheol by being caught up in the air is intellectually weighty. If we grant the possibility that Paul may have been familiar with notions preserved in rabbinic sources regarding the image of eschatological affairs, then it is worth considering whether the mechanics of the parousia according to Paul may be grounded in the same concepts. Certainly the similarities are striking, and may allow for new avenues of interpretation of Paul's words. Like the Korahites, the Thessalonians will be saved from falling into Sheol because they will be lifted up in the air. The logistics of the last day are expressed using midrashic eschatological physics. Moreover, the rabbinic interpretations of Isa 60.8 insist that we should consider the possibility that the clouds themselves-and perhaps the Jerusalem that sits amid them-are the eschatological destination of the saved. There is no need to push the journey further. The structural, thematic, conceptual, and functional parallels between 1 Thess 4.16-17 and rabbinic expectations about the Day of the Lord are illuminating and suggestive. Taken seriously, the similarities both press hard against assumptions in Pauline scholarship and offer some intriguing solutions to questions that have plagued interpreters of 1 Thessalonians.

41 For the translation 'dead who are in Christ' see Frame, Epistles of St. Paul to the Thessalonians, 175. For the latter view see Best, Commentary on the First and Second Epistles to the Thessalonians, 197 and Malherbe, Letters to the Thessalonians, 275. The Vulgate opts for the former sense, rendering the clause 'et mortui qui in Christo sunt'. 